\title{
A Pathway to Educational Accountability: The Relationship between Effective School Characteristics and Student Achievement ${ }^{\mathrm{i}}$
}

\author{
Yurdagül Günal ${ }^{1, *}$, R. Nükhet Demirtaşlı² \\ ${ }^{1}$ Department of Educational Sciences, Faculty of Educational Sciences, Karadeniz Technical University, Turkey \\ ${ }^{2}$ Department of Measurement and Evaluation in Education, Faculty of Educational Sciences, Ankara University, Turkey
}

Copyright $(02016$ by authors, all rights reserved. Authors agree that this article remains permanently open access under the terms of the Creative Commons Attribution License 4.0 International License.

\begin{abstract}
The aim of this study is to determine perceptions of secondary school students towards effectiveness of their school in terms of effective school characteristics such as "Secure and Regular Environment", "High Academic Expectations", "Instructional Leadership", "Learning Opportunities", "Monitoring School Learnings" and "Positive School-Parent Relationship", and to determine the predictive power of such perceptions for student achievement (in terms of year-end academic average grade). In this study, the data on student perceptions of school effectiveness and student achievement were collected by "The Scale for Effective School (SFES)" which is developed by Günal [1]. The validity evidences on SFES were obtained by explanatory factor analysis and confirmatory factor analysis methods. The CFA yielded good fit indices $\left(\operatorname{RMSEA}_{(0.042)}\right)$ in terms of construct validity of SFES. These results revealed that the measuring construct of the scale is statistically significant and consistent. As an evidence of internal reliability of the SFES, Cronbach's alpha coefficient for total scale was computed as $\alpha=0.91$. For the main study, participants $(n=4472)$ were comprised of students attending the grades from 5 to 8 in 13 secondary schools in the centre of Trabzon during the 2012-2013 academic year. The schools were selected according to the criteria of transportation convenience. Collected data by SFES were analyzed by multivariate regression analysis method. According to the participants' perceptions, the most effective school dimension was found as "Instructional Leadership". The results of the multivariate regression analysis reveal that variables (Instructional Leadership, High Academic Expectations, Monitoring School Learnings, Positive School-Home Relationship, Learning Opportunities offered to all students) of effective schools all together explain $27 \%$ of students' year-end academic achievement scores.
\end{abstract}

Keywords Effective School, Educational Accountability, Student Achievement

\section{Introduction}

Education is one of the oldest activities in mankind history. Education emerges as a social problem because it is used for transferring, preserving, changing and refreshing the social values in order to equip individuals with personality, value and ability [2]. Education is a multifaceted concept difficult to define that is associated with many disciplines. Although there is not a single definition accepted by all, education is considered as "the process of deliberately causing desired changes in individuals' behaviour through their experiences [3]. In another definition, education is defined as entire of the activities towards gaining of certain mental, physical, emotional and social abilities, behaviours and knowledge in the process of humans' trying to perform their own inner nature as a purposeful action for acquisition of individual development and social competence [4]. School is the leading place which formal and continuous educational facilities are implemented in. The main responsibility of schools is to educate individuals who fulfil expectations from society and the requirements of 21 st century. Since schools left behind to meet these high expectancies, many countries have been attempting to change this undesirable situation $[5,6,7,8,9,10]$ These efforts have brought "educational accountability" as a crucial concept in educational systems. Educational accountability has strong connections with effective school. Effective school is described by Edmonds [5] as the place to acquire basic skills for academically powerful and weak students. In this regard; effective school can be defined as a continuously learning and improving organization in which all students can learn, the focus of which is the equality and quality elements, resources are equally available to all students, providing students and employees with a safe environment open for development, and accountable to all stakeholders. In literature, many effective school characteristics have been illustrated. The most common features for effective schools are Secure and Regular Environment, Teaching Leadership, High Academic Expectations, Monitoring School Learning's, Positive School-Home Relationship, Learning Opportunities 
offered to all students [11]. These effective school characteristics have been explained as follows:

Secure and Regular Environment: Ensuring safety in school and feeling safe by students, teachers, school employees in school is also a prerequisite for the sustainability of educational activities at school [12]. Marzano [13] points out that teachers and students need to feel safe at school in order to have the psychological energy for learning or teaching. In Lezotte [14] a safe and orderly environment is defined as a regular and purposeful place where there is no threat of physical harm. In effective schools, an organized, purposeful and professional atmosphere prevails which is away from the threat of physical harm.

Instructional Leadership: The role of the leader in institutions or organizations is to question what needs to be done. In this sense, school principals, as instructional leaders, are responsible for constantly investigating and developing New teaching methods and techniques, and strategies which will provide more successful teaching and more permanent learning [15]. Lezotte \& Snyder [10] emphasize instructional leadership by school principal in an effective school and continual transfer of this mission to not only staff but also students and parents.

High Academic Expectations: The staff in effective schools believe that all students have the capacity to earn the basic school skills and act accordingly. In a survey conducted in two schools in New York in 1974, Edmonds found out that teachers and administrators had high academic expectations in high-performance schools, whereas the staff in low-performance schools were pessimistic about their ability to affect students [5].

Monitoring School Learnings: Academic achievement of students in effective schools often must be measured using a variety of assessment tools [14]. The results of the assessment should be used to improve student performance and to improve the curriculum. Assessments are sources providing information on what is best taught and what remains missing. Assessments are used to give feedback to students, address their learning deficiencies, improve the curriculum as a whole, to see the education and instruction process and to make instructional decisions for each student.

Positive School-Home Relationship: There are many factors inside and outside school which affect academic achievement of students. Among other external factors, family has an important impact on both social and academic achievement of students [16, 17]. Family's dealing with children has a positive impact on children's social and cognitive development [18]. According to Lezotte [14] parents should understand and support the essential mission of the school in an effective school. In other words, parents in effective schools should assume an important role in the success of the school.

Learning Opportunities Offered to All Students: In effective schools, teachers devote a lot of time for teaching of basic skills in the classroom. At the same time, they should take extra time for slow learners [19, 14]. Providing the learning opportunities is the time spared for students' gaining important skills. Edmonds [5] argues that all children can learn in effective schools. In this case, the time devoted to instruction is determined by students' needs in effective schools. DuFour, DuFour, Eaker \& Karhanek [20] stated that learning does not change in an effective school; however, the necessary time and support need to be provided by schools.

The aim of this study is to investigate perceptions of secondary school students towards effectiveness of their school in terms of effective school characteristics and also, to estimate the degree of prediction of these effective school characteristics in student achievement (in terms of GPA).

\section{Method}

\section{Participants}

In this research, the study group was comprised of 4472 students attending the grades from 5 to 8 in 13 secondary schools in Trabzon. They participated to this study as voluntarily. The schools and number of students participating in the research are displayed in Table 1.

Table 1. Student Population in Study Schools and Number of Participants

\begin{tabular}{|c|c|c|c|c|}
\hline \multirow[t]{2}{*}{ School } & \multicolumn{4}{|c|}{ Grade } \\
\hline & 5 & 6 & 7 & 8 \\
\hline Ata Secondary School & 92 & 69 & 77 & 96 \\
\hline Kanuni Secondary School & 80 & 63 & 76 & 109 \\
\hline Zehra Kitapçıoğlu Secondary School & 48 & 87 & 34 & 58 \\
\hline Kaledibi Secondary School & 57 & 69 & 58 & 76 \\
\hline Bedri Rahmi Eyüboğlu Secondary School & 92 & 91 & 95 & 98 \\
\hline Bener Cordan Secondary School & 96 & 99 & 99 & 141 \\
\hline Beşirli IMKB Secondary School & 98 & 100 & 99 & 100 \\
\hline Cudibey Secondary School & 100 & 100 & 98 & 100 \\
\hline Cumhurriyet Secondary School & 102 & 76 & 75 & 104 \\
\hline General Total & \multicolumn{4}{|c|}{4472} \\
\hline
\end{tabular}


Table 2. Descriptive Statistics for Participants' Scores from Variables of the SFES

\begin{tabular}{cccccccc}
\hline Variable & Mean & Median & Mode & Minimum & Maximum & s & Range \\
\hline Instructional Leadership & 17.13 & 18 & 19 & 7 & 21 & 3.12 & 7 \\
Positive Parent-School Relationship & 16.60 & 17 & 18 & 7 & 21 & 3.16 & 7 \\
Secure and Regular Environment & 9.21 & 10 & 10 & 4 & 14 & 2.05 & 10 \\
Learning Opportunities & 7.60 & 8 & 9 & 3 & 9 & 1.48 & 6 \\
Monitoring School Learnings & 7.51 & 8 & 9 & 3 & 9 & 1.55 & 6 \\
High Academic Expectations & 6.81 & 7 & 8 & 3 & 9 & 1.70 & 6 \\
Total Scale Score & 64.70 & 67 & 68 & 27 & 81 & 12.92 & 54 \\
\hline
\end{tabular}

Table 3. Multivariate Regression Analysis Results regarding Variables of Effective Schools Contributing to Predicting Students' Academic Achievement

\begin{tabular}{|c|c|c|c|c|c|c|c|}
\hline Variable & B & Standard Error ${ }_{B}$ & $\beta$ & $\mathrm{T}$ & $\mathrm{P}$ & Binary $r$ & Partial $r$ \\
\hline Constant & 30.63 & 1.194 & - & 25.65 & .000 & - & - \\
\hline Instructional Leadership & .38 & .122 & .08 & 3.14 & $.002 *$ & .45 & .05 \\
\hline Positive Parent-School Relationship & .77 & .071 & .17 & 11 & $.000^{* *}$ & .39 & .16 \\
\hline Secure and Regular Environment & 1.24 & .121 & .18 & 10.22 & $.000^{* *}$ & .42 & .15 \\
\hline Learning Opportunities & .620 & .18 & .06 & 3.45 & $.000^{* *}$ & .37 & .05 \\
\hline Monitoring School Learnings & .026 & .17 & .00 & .155 & .880 & .34 & .00 \\
\hline High Academic Expectations & 1.31 & .174 & .16 & 7.53 & $.000^{* *}$ & .41 & .11 \\
\hline \multicolumn{8}{|c|}{$\begin{array}{c}\mathrm{R}=0.518 \mathrm{R}^{2}=0.268 \\
\mathrm{~F}_{(6,4465)}=272.747 \mathrm{p}=0.000\end{array}$} \\
\hline
\end{tabular}

\section{Instrument and Data Analysis}

\subsection{The Scale for Effective School-Student Form}

For research objectives, a measure of school effectiveness was needed. For this, the scale for effective school-SFES- is developed by Günal [1]. The SFES-Student Form consists of two parts. Part one includes family, demographic information such as school and grade of students. Part two consists of 27 three-point Likert-type items regarding variables of effective school. Part one was used to obtain information about students including "Parents' education level", "number of books at home", "opportunities at home", "gender" and "grade levels". The second part consists of the 27-item SFES comprised of variables such as "Positive School-Parent Relationship", "Instructional Leadership", "Secure and Regular Environment", "High Academic Expectations", "Monitoring School Learnings" and "High Academic Expectations". The validity evidences were obtained from data by Explanatory Factor Analysis (EFA) and Confirmatory Factor Analysis (CFA) methods. The CFA yielded good fit indices $\left(\operatorname{RMSEA}_{(0.042)}\right) G F I_{(0.92)}$ and $A G F I$ (0.90). These results supported the construct validity of SFES. As an evidence of internal reliability of the SFES, Cronbach's alpha coefficient for total scale was computed as 0.91 .

\section{Procedure}

This study is correlational (descriptive) research. Correlational studies investigate the possibility of relationships between two or more variables are studied without any attempt to influence them [21;287]. In this research, the relationships between effective school variables and student achievement were investigated. First of all, descriptive statistics were computed for each subscale of SFES to determine the level of importance of effective school dimensions from the students' points of view. After that, collected data were analysed by multivariate regression analysis method (MVRAM) in accordance with research purpose.

\section{Findings}

According to results of the descriptive statistics, the importance levels of effective school dimensions from the students' point of view were found respectively as "Instructional Leadership, Positive School-Parent Relationship, Secure and Regular Environment, Learning Opportunities Offered to All Students in School, Monitoring School Learnings and High Academic Expectations. Descriptive statistics regarding participants' responses to variables in the SFES are displayed in Table 2.

The contribution of variables of effective schools to predict students' year-end overall academic achievement was resolved with the "Multivariate Regression Analysis". The results are shown in Table 3 . 
Also, the MVRA gave meaningful results; total SFES scores were accounted for $27 \%$ of variation $\left(R^{2}: 0.268 p<.05\right)$ in students' GPAs. According to standardized $\beta$ (beta) coefficients in the regression equation, the five dimensions of effective schools could predict students' achievements significantly, which were Secure and Regular Environment, High Academic Expectations, Positive School-Parent Relationship, Instructional Leadership, and Learning Opportunities offered to all students in school, respectively.

The dimension of "Monitoring School Learning" was not found to contribute significantly to explain academic achievement only. The other dimensions help predict academic achievement at significant level. According to the standardized regression coefficient ( $\beta$ ), relative importance of predictive variables on academic achievement was found as follows: High Academic Expectations, Secure and Regular Environment, Positive School-Parent Relationship, Learning Opportunities, Instructional Leadership, and Monitoring School Learnings. Therefore, one-unit increase in "Positive Parent-School Relationship" brings 0.77 units of significant contribution to academic achievement, one-unit increase in "High Academic Expectations" results in 1.31 units, one-unit increase in "Learning Opportunities" results in 0.63 units, one-unit increase in "Secure and Regular Environment" brings 1.24 units, lastly, one-unit increase in "Instructional Leadership" results in 0.38 units of significant contribution to academic achievement.

\section{Discussion}

The study yielded similar results to other studies in the literature. According to the literature, there is strong relationship between students' achievement and key characteristics of effective schools such as high academic expectations, monitoring school learnings, secure and regular school environment and teaching leadership [22, 23] In this study, "High Academic Expectations" was found to be the most effective schooling factor on students' academic achievement. High academic expectation plays a key role in effective schools. As a consequence of hundreds of trials, Rosenthal \& Jacobson [24] found out that teacher expectations have significant impacts on student performance. They pointed out that if teachers have high expectations regarding students' performance, the latter act accordingly. Described as the "expectation effect" or "Pygmalion effect" from the Greek mythology in psychology, this case is described as individuals' acting in accordance with others' expectations regarding them after a while [25]. Another variable providing significant contribution was found as "Secure and Regular Environment". Marzano [13] points out that teachers and students need to feel safe at school in order to have the psychological energy for learning or teaching. It is also added that a safe and regular environment is of critical importance for academic achievement. A safe and regular environment allows a suitable setting for development of the other dimensions of an effective school [10]. Moreover, physical facilities of school have a significant impact on student achievement and teacher effectiveness. Another factor of effective schools was found to be "Positive School-Parent Relationship" from the participants' views. The study seems to be supporting many other studies in the literature as it indicates the effect of positive school-parent relations on students' achievement. [26,27]. Jeynes (2005) found out in his study that children whose parents often visit school to discuss with teachers could perform higher than their peers whose parents do not visit school or attend meetings with teachers. The same study also examined ways of parental contribution to education. Consequently, higher academic achievement was measured from children whose parents have positive relationships with their school, are in contact with school staff, provide environments which support learning at home, talk about school and are interested in the children's achievement level at school [28]. Furthermore, learning opportunity provided for students in schooling was reported to be significant and important by participants. The time invested for learning of students and methods used by teachers provide learning opportunities for students. It is thought that teachers need to regulate learning environments considering individual differences in education. Teachers need to consider certain factors while creating an effective schooling environment. These factors include determination of students' ways of learning in order to choose appropriate learning and teaching methods, applying of an objective measurement and evaluation process and giving feedback. Similar studies in the literature found out that it is essential for effective schooling to test whether learning takes place, and to give feedback accordingly [29]. From this point of view, it can be argued that monitoring of school learning's is important. Identifying pupils' learning levels, that is the extent at which learning achievement takes place, is important for effective learning. It would help effective learning to determine and improve learning deficiencies in a timely manner. Monitoring of students' learning includes teachers' debating with students and asking questions about topic taught, checking their homework individually, and testing to highlight monitoring and results [30]. In our study, no significant attribution was made by students to monitoring of students' learning as a factor of effective schooling. In the TIMSS 1999 survey on teachers by OECD, for the question 'For what purposes is measurement and evaluation carried out at schools?" the teachers in Turkey often cited "grading" [31] In the light of these findings, it could be argued that monitoring of pupils' learning in Turkey is mostly regarded as a result-oriented work carried out to give grades, rather than giving feedback or improving the learning process. This could account for the finding that the participants do not perceive monitoring as a significant factor. Lastly, "Instructional Leadership" was found as relatively the most effective variable of effective school dimensions by participants. In this case, especially instructional leadership of school principals becomes important. Education is 
undergoing major changes in terms of both content and implementation and management and countries are revised education systems in accordance with the necessities of this century Within the scope of the restructuring work in education, one of the most frequently addressed subjects is the instructional leadership of school principals. In this direction, "school leadership" issue has gained a special importance [5, 32,33, 34, 35].

\section{Recommendations}

Effective schools are managed by effective leaders. Today, school leadership has gained a special importance. In this direction, especially managerial and leadership skills of school principals should be brought to the forefront ([27]OECD, 2009). To this end, school principals can be encouraged to do master education especially in the field of school management or in any branch of educational sciences. Selecting school principals from experienced teachers with a master's degree in school management might contribute to effectiveness of school principals and thereby to effectiveness of the school. Teachers, school principals and parents' high academic expectations and their expressing such expectations might be influential on students' positive self-perception and self-confidence. Therefore, it could be useful that guidance service of schools might give seminars on learners' psychology, positive personality development, self-confidence and self-efficacy for school principals, teachers and parents. Students should be provided a safe and orderly educational environment where they can feel happy and safe. At the same time, a classroom and school climate should be created where students feel valued and motivated. Family and school cooperation should be improved in this regard and activities should be organized to increase parents' involvement in school. Furthermore, it is recommended to design the inside and outside of school environment according to students' needs and to increase attractiveness. In this scope; a canteen, a cafeteria, a library rich in resources, indoor and outdoor sports fields can be designed. Therefore, to establish a survey center will be a necessity and also a comprehensive effort. Thus, needs and opinions of all educational stakeholders (teachers, students, parents and school principals) can be monitored by survey regularly and analysing related data for the purposes of survey.

\section{REFERENCES}

[1] Günal, Y. Etkili okul değişkenlerinin öğrenci başarısı ile ilişkisi ve okul hesap verebilirliği. (Yayımlanmamış doktora tezi). Ankara Üniversitesi, Eğitim Bilimleri Enstitüsü, Ankara; 2014.

[2] Bilhan, S. Eğitim felsefesine giriş. Ankara Üniversitesi Yayınları. Ankara; 1991.
[3] Ertürk, S. Son makalesi Türkiye'de eğitim felsefesi sorunu. Hacettepe Üniversitesi Eğitim Fakültesi Dergisi; 1988 (3), 11-16

[4] Gökçe, F., \& Başgelen, N. Değişme sürecinde devlet ve eğitim. Ankara. Pegem akademi yayınları; 2009.

[5] Edmonds. R.R. Effective schools for the urban poor. Educational leadership; 1979. Retrieved from http:/www.midwayisd.org/cms/lib/TX01000662/ Centricity/Domain/8/2.\%20Edmonds\%20Effective\%20Scho ols\% 20Movement.pdf. 18 March 2013

[6] Sammons, P., Hillman, J., \& Mortimore, P. Key characteristics of effective schools A review of school effectiveness research. For the office for standards in education. Submitted to school effectiveness and school improvement journal; 1995.

[7] Heneveld W., \& Craig, H. Schools Count. World Bank project designs and the quality of primary education in Sub-Saharan Africa; 1996.

[8] Scheerens, J. İmproving school effectiveness. Fundamentals of educational planning No:68; 2005.

[9] Bergeson, T., \& Davidson, C. Nine characteristics of high-performing schools. Assessment and student; 2007.

[10] Lezotte, L.W., \& Snyder, K.M. What effective schools do? Solution Tree Press. United States of America; 2011.

[11] Center for Effective Schools [CCE] Effective schools model 7 correlates of effectiveness. Oklahoma University; 2001.

[12] Pişkin, M., Öğülmüş, S., \& Boysan, M. Güvenli okul ortamı oluşturma öğretmen ve yönetici el kitabı. TÜBİTAK, Ankara üniversitesi; 2011.

[13] Marzano, R.J. Using Data: Two wrongs and a right. Educational leadership; 2003. 60 (5), 55-60. Retrieved from http://www.ascd.org/publications/educational-leadership/feb 03/vol60/num05/Using-Data@-Two-Wrongs-and-a-Right.as px. 22 July 2014.

[14] Lezotte, L.W. Correlates of effective schools. The First and second generation effective schools products, Ltd., Okemos, MI; 1991.

[15] Özdemir, S., \& Sezgin, F. Etkili okullar ve öğretim liderliği. Manas Sosyal Bilimler Dergisi; 2002. 2(3), 266-282.

[16] Aslanargun, E. Okul - aile işbirliği ve öğrenci başarısı üzerine bir tarama çalışma. Sosyal Bilimler Dergisi; 2007. (18), 120-135.

[17] Kaplan, D.S., Liu, X., \& Kaplan, H.B. Influence of Parents' Self-Feelings and Expectations on Children's Academic Performance. Journal of Educational Research, v94 n6 p360-70 Jul-Aug 2001. Retrieved from http://eric.ed.gov/?id=EJ631750. 20 July 2015.

[18] Sheldon, S.B., \& Epstein J.L Getting students to school: Using family and community Involvement to Reduce Chronic Absenteeism; 2004. Retrieved from files.eric.ed.gov/fulltext/ EJ794822.pd. 11 May 2014.

[19] Hopkins, D., \& Levin, B. Educational reform and school improvement. NIRA Review. Summer; 2000.

[20] DuFour, R., DuFour, R., Eaker, R., \& Karhanek, G. Whatever it takes: How professional learning communities respond when kids don't learn. Bloomington, IN: Solution Tree; 2004. 
[21] Fraenkel, J.,R. \& Wallen, N., E. How to Design and Evaluate Research in Education; McGraw-Hill Companies,; 1993.2nd Edition.

[22] Reynolds, D., Bollen, R., Creemers, B., Hopkins, D., Stoll, L., \& Lagerweij, L. (1996). Making good schools: Linking effectiveness and school improvement. London Routledge.

[23] Wilsen, B, M.L. Abbott, Joireman, J., \& Stroh, H.R. (2002). The relations among school environment variables and student achievement: A structural equation modeling approach to effective schools research. Washington School Research Centre. Technical Report 4.

[24] Rosenthal, R., \& Jacobson, L. Pygmalion in the classroom. The Urban Review; 1968. 1 (3), pp 16-20. Retrieved from http://link.springer.com/article/10.

1007\%2FBF02322211\#page-1. 10 April 2014.

[25] Chang, J. "A case study of the "Pygmalion Effect": Teacher expectations and student achievement. International Education Studies 4(1). Retrieved from www.ccsenet.org/ies; 2011. 12 May 2014.

[26] Ghysens, L. Parents', teachers' and children's perception of parental involvement in relation with pupils' learning achievement and wellbeing. 7th International Conference of the European Research Network about Parents in Education DIVERSITY IN EDUCATION ERNAPE; 2009. ISBN 978-91-86238-82-2

[27] Amatea, E.S., \& West, C.A. (2007). Joining the conversation about educating our poorest children: Emerging leadership roles for school counselors in high poverty schools.
Professional School Counseling, 11, 81-89.

[28] Jeynes, W. H., Parental Involvement and Student Achievement: A Meta-Analysis. Harvard Family Research Project. 2005. (n.d.) http://www.hfrp.org/publications-resour ces/browse-our-publications/parental-involvement-and-stude nt-achievement-a-meta-analysis

[29] Hopkins, D. and Levin, B., (2000). Educational Reform and School Improvement. NIRA Review. Summer 2000.

[30] Professional Learning in Effective Schools The Seven Principles of Highly Effective Professional Learning. http://www.curriculum.edu.au/leader/professional_learning_i n_effective_schools, 12689.html?issueID=10183. 2005.

[31] Arıkan, S, Çelen, Ü., Gülleroğlu, D., Gültekin, S., Kilmen, S.,\& Köse, İ.A.,(Ed.).Demirtaşl1, R.N.2014. EDGE Akademi.

[32] Brookover, W., \& Lezotte, L.W. (1979). Changes in school caracteristics coincident with changes in student achievement (executive summary). Institute for research on teaching.

[33] OECD. Review on evaluation and assessment frameworks for improving school outcomes.; 2009.

[34] Zhao, Y., Lustick, D., \& Yang, W. Research and the five dimensions of effective schools: A self-assessment guide for the chinese educator. US-China Center for Research on Educational Excellence and Michigan State University; 2005.

[35] Leithwood, K., \& Earl, L. Educational accountability effects: An international perspective. Peabody Journal of Education; 2000. 75(4), 1-18. Retrieved from http://www.jstor.org/stabl e/1493050?seq=1\#page_scan_tab_contents

\footnotetext{
i This study was developed from the 1st author's $\mathrm{PhD}$ research at Ankara University, Faculty of Educational Sciences, Department of Measurement and Evaluation in Education supervised by 2 nd author.
} 